\title{
Atopy phenotype in subjects with variants of the $\beta$ subunit of the high affinity IgE receptor
}

\author{
Airong Li, Julian M Hopkin
}

\begin{abstract}
Background - FceRI plays a central role in atopy, thus genetic variants of FceRI- $\beta$ may alter receptor function to enhance atopic responses and may manifest as a more severe atopic phenotype and more symptomatic atopic disease. The immunological and clinical features of atopy in children with and without the Leu 181 variant of FcERI- $\beta$ were compared.

Methods - Sixty British nuclear families, including 10 families with the FceRI- $\beta$ variant Leu 181 , recruited via a young proband with atopic asthma were analysed for atopic parameters including total IgE, specific IgE, and clinical atopic disorder. Results - Compared with other children (combined atopic and non-atopic subjects), maternally inherited Leu 181 was associated with increased levels of total IgE (odds ratio (OR) $4.82,95 \%$ confidence interval (CI) 1.02 to $27.66, p<0.01$ ) and a positive IgE response to grass pollen allergen (OR 7.45, 95\% CI 1.56 to 35.52 , p $<0.005$ ) but not wheeze (OR 1.97, 95\% CI 0.56 to 7.69 ), asthma (OR 2.25, 95\% CI 0.65 to 7.85 ), or required medications (OR 0.95 , $95 \%$ CI 0.29 to 3.14$)$. There were trends for each atopic parameter to be more marked in atopic children with maternally inherited Leu 181 than in atopic children without Leu 181. Children with maternal Leu 181 had significantly raised eosinophils but there was no difference in basophil levels compared with other atopic children.

Conclusions - The Leu 181 variant of FceRI- $\beta$, or another identified variant in linkage disequilibrium, may promote the development of atopy.

(Thorax 1997;52:654-655)
\end{abstract}

Osler Chest Unit, The Churchill

Hospital,

Oxford OX3 $7 \mathrm{LJ}$, UK

A Li

J M Hopkin

Correspondence to: Dr J Hopkin.

Received 18 July 1996 Returned to authors 28 October 1996

Revised version received

1 April 1997

Accepted for publication

14 April 1997
Keywords: atopy, genetics, FceRI.

Atopy results from interaction between genetic and environmental factors and is one important cause of asthma and rhinitis. Initially controversial, a number of molecular genetic studies now show genetic linkage or association between atopy and polymorphisms at chromosome $11 \mathrm{q} 13 .{ }^{1-3}$ There is association between the variant Ile181Leu (Leu 181) of the $\beta$ subunit of the high affinity IgE receptor (FcERI- $\beta)$ at this chromosome 11q location and atopy by maternal descent. ${ }^{4}$ The identification of this variant DNA has proved problematic, perhaps because of protein/DNA binding at the site, but the variants we report have been confirmed by direct DNA sequence analysis. In this study we have compared the immunological and clinical features of atopy between the subjects with and without the Leu 181 variant, as genotyped in our previous study, ${ }^{4}$ and discuss the correlation of various atopic characteristics with maternal transmission of the Leu 181 allele.

\section{Methods}

Sixty nuclear families ascertained through an atopic asthmatic proband (aged between 5-25) with one other sibling and both parents available for testing were examined. Of these, 10 families had Leu 181 segregating, ${ }^{4}$ there were 13 atopic children with maternally inherited Leu 181 in these 10 families, and 122 children age matched from the other 50 nuclear families. Atopy was defined as one of the following features or any of their combinations: positive skin prick test (greater than or equal to $2 \mathrm{~mm}$ above negative control), positive specific IgE RAST (class 1 or above), or raised total $\operatorname{IgE}$ (greater than published normal values for children or $100 \mathrm{kU} / 1$ for non-smoking adults).

\section{Results}

Of 13 children with maternally inherited Leu 18111 had asthma or rhinitis, or both, and 10 had eczema. Significantly raised total IgE levels (OR 4.82, 95\% CI 1.02 to 27.66, p <0.01) and positive skin prick testing to grass pollen allergen (OR 7.45, 95\% CI 1.56 to 35.52, p $<0.005$ ) was found in the comparison between the children with maternal Leu 181 and the other children (combined atopic and nonatopic subjects). When compared with the atopic children without maternal Leu 181, those with Leu 181 showed more pronounced atopy for each characteristic considered. However, these trends were statistically significant only for greater positive skin prick test reactions to grass pollen and eosinophil count, and there was no significant increase in total serum IgE levels or basophil count in the subjects with Leu 181. There was no significant association between the presence of maternal Leu 181 and the asthmatic manifestations of atopy - wheeze 
Table 1 Comparison of children with maternal Leu 181 and other atopic children

\begin{tabular}{|c|c|c|c|c|c|}
\hline Parameters & $\begin{array}{l}\text { Leu 181 } \\
(n=13)\end{array}$ & $\begin{array}{l}\text { Others } \\
(n=86)\end{array}$ & $\begin{array}{l}\text { Odds } \\
\text { ratio }\end{array}$ & $95 \% C I$ & $p$ value \\
\hline \multicolumn{6}{|c|}{ Total IgE $(k U / 1)$} \\
\hline $\begin{array}{l}>100 \\
<100\end{array}$ & 11 & 62 & 237 & 0.49 to 11.36 & NS \\
\hline \multirow{2}{*}{\multicolumn{5}{|c|}{ SPT-GP $(>2 \mathrm{~mm})$}} & \\
\hline Positive & 10 & & & & \\
\hline Negative & 2 & 37 & 3.78 & 1.28 to 18.36 & 0.049 \\
\hline \multicolumn{6}{|l|}{ Wheeze } \\
\hline Yes & 10 & 54 & 107 & 0.56 to 769 & NS \\
\hline No & 3 & 32 & 1.91 & 0.56 to 7.69 & NS \\
\hline \multicolumn{6}{|l|}{ Asthma } \\
\hline $\begin{array}{l}\text { Yes } \\
\text { No }\end{array}$ & 9 & 43 & 2.25 & 0.65 to 7.85 & NS \\
\hline $\begin{array}{l}\text { No } \\
\text { Medication }\end{array}$ & \multicolumn{5}{|c|}{ Medications } \\
\hline $\begin{array}{l}\text { Medication } \\
\text { Yes }\end{array}$ & 8 & 54 & 005 & 029 to 3.14 & NS \\
\hline No & 5 & 32 & 0.95 & 0.29 to 3.14 & NS \\
\hline
\end{tabular}

SPT-GP $=$ skin prick test to grass pollen; $\mathrm{NS}=$ not significant.

(OR $1.97,95 \%$ CI 0.56 to 7.69 ) and asthma (OR 2.25, 95\% CI 0.65 to 7.85 ) or required medications (OR 0.95 , 95\% CI 0.29 to 3.14 ) - in comparison with other atopic children, although the numbers with Leu 181 were small (table 1).

\section{Discussion}

The significant association between the presence of maternal Leu 181 and raised IgE levels in comparison with other children (combined atopic and non-atopic) supports the possibility that FceRI- $\beta$ may be the atopy locus on chromosome 11q13. A strong association has been shown between an intronic variant of FceRI- $\beta$ and each of atopic asthma, atopic rhinitis, and atopic eczema in a Japanese population. ${ }^{5}$ A coding variant of FceRI- $\beta$, changing amino acid residue 237 from glutamic acid to glycine, shows a strong association with atopy and atopic asthma in Australian and Japanese populations. ${ }^{67}$ There are several possible genetic variant(s) within FceRI- $\beta$ or its controlling elements or perhaps a contiguous locus involved in atopy; this can only be resolved by more detailed genetic association studies at this location, proceeding to functional investigation.

Leu 181 lies within the fourth transmembrane domain of FceRI- $\beta$, a critical region within the $\beta$ subunit for efficient and intact FceRI display, and might therefore influence receptor function in some way - for instance, by enhanced receptor binding for IgE or enhanced signal transduction - with a range of possible consequences in the many cells expressing FceRI. ${ }^{4}$ Mast cells and basophils might release more mediators which promote local inflammation and thereby symptoms, or might enhance expression of cell contact signal including CD40 ligand in the presence of interleukin 4, causing more local B lymphocyte $\operatorname{IgE}$ production. ${ }^{8}$ In antigen presenting dendritic cells ${ }^{9}$ there might be a resultant enhancement of presentation of allergen; in the eosinophil ${ }^{10}$ there might be enhanced release of cytotoxic proteins.

The association of Leu 181 with such diverse atopic indices as raised total serum IgE, specific sensitisation to grass pollen, and increased eosinophil counts does not allow prediction of the likely cellular site or mechanism of action. Thus, broad ranging experiments on the possible functional consequences of the Leu 181 mutation and other mutations of FceRI- $\beta$ are required.

1 van Herwerden L, Harrap S, Wong ZYH, Abramson MJ, Kutin JJ, Forbes AB, et al. Linkage of high affinity gene with bronchial hypereactivity, even in the absence of atopy. Lancet 1995;346:1262-5.

2 Doull MI, Lawrence S, Watson M, Begishvili T, Beasley RW, Lampe F, et al. Allelic association of gene markers on chromosome 5 and $11 \mathrm{q}$ with atopy and bronchial hyperresponsiveness. Am $\mathcal{f}$ Respir Crit Care Med 1996;153: hyperres $1280-4$.

3 Neely JD, Duffy DL, Breazeale DR, Freidhoff LR, Schou MS, Kautzky-Ehrlich E, et al. Linkage analysis of IgE and chromosome 11q13 markers. Am f Respir Crit Care Med 1996;153:A767.

4 Shirakawa T, Li A, Dubowitz M, Dekker JW, Shaw AE, Faux JA, et al. Association between atopy and variants of the $\beta$ subunit of the high-affinity immunoglobulin $\mathrm{E}$ receptor. Nature Genet 1994;7:125-30.

5 Shirakawa T, Mao XI, Sasaki S, Kawai M, Morimoto $K$, Hopkin J. Association between FceRI- $\beta$ and atopic disorder in a Japanese population. Lancet 1996;347:394-5.

6 Hill MR, Cookson WOCM. A new variant of the $\beta$ subunit of the high-affinity receptor for immunoglobulin $\mathrm{E}$ (Fc\&RI$\beta$ E237G): associations with measures of atopy and bron$\beta$ E237G): associations with measures of atopy and bron62.

7 Shirakawa T, Mao XQ, Sasaki S, Enomoto T, Kawai M, Morimoto K, et al. Association between atopic asthma and a coding variant of FceRI- $\beta$ in a Japanese population. and a coding variant of FceRI- $\beta$ in

8 Gauchat JF, Henchoz S, Mazzei G, Aubry GTP, Brunner $\mathrm{T}$, Blasey F, et al. Induction of human IgE synthesis in B cells by mast cells and basophils. Nature 1993;365:340-3

9 Grabbe J, Haas N, Hamann K, Kolde G, Hakimi J, Cremer $\mathrm{B}$, et al. Demonstration of the high-affinity IgE receptor on human skin cells. Br f Dermatol 1993;129:120-3.

10 Busse WW, Sedgwick JB. Eosinophils in asthma. Ann Allergy 1992;68:286-90. 